\title{
TYING ARRANGEMENTS AND THE LEVERAGE PROBLEM
}

\author{
WARD S. BOWMAN, JR $\uparrow$
}

IN antitrust law, the conclusion that tying the sale of a second product to a patented product is automatically illegal has been accepted by courts for forty years. ${ }^{1}$ Under this theory, tying is harmful because it creates a new monopoly wholly outside the patent. Conditioning the sale or lease of one commodity on the sale or lease of another, a practice known as a tying agreement or a tie-in, is generally considered a trade-restraining device. The recent Report of the Attorney General's Committee to Study the Antitrust Lazes declares that the purpose of a tying contract is monopolistic exploitation. ${ }^{2}$ This exploitation is achieved by "artificially extending the market for the 'tied' product beyond the consumer acceptance it would rate if competing independently on its merits and on equal terms."3 The view that tying contracts allow the wielding of monopolistic leverage is widely accepted.

"Wielding monopolistic leverage" is an ambiguous phrase. A distinction can usefully be made between leverage as a revenue-maximizing device and leverage as a monopoly-creating device. The first involves the use of existing power. The second requires the addition of new power. ${ }^{4}$ In both cases monopoly is

$\dagger$ Associate Professor of Law and Economics, Yale Law School.

This Article attempts to explore the relationship between product complementarity and tying sales as contrasted with other explanations which have been offered. A "complementarity" view of tying sharply contrasts with other positions in terms of what is called the "leverage" problem. In particular, two explanations have been formulated by Professor Aaron Director-tying as an evasion of price regulation and tying as a counting device for price discrimination. I have reconstructed these explanations as I understood them from previous discussions with him over a period of years ending in 1956 at the University of Chicago Law School. Professor Director, of course, bears no responsibility for my interpretation; my debt to him is great, however, not only for encouraging my interest in the tie-in problem but more basically for providing both a theory and an application of the "evasion" and the "counting" cases, reproduced here. The conclusions contained in this Article derive from comparison of these examples with the "complementarity" example to determine whether or not tie-ins create new monopoly.

The relationship between product complements and the use of the tying device was developed jointly with John S. McGee, Associate Professor in the School of Business at the University of Chicago. He has been a substantial contributor to the analysis in this Article; in addition he has read and criticized the manuscript in several drafts.

1. The rule was established in Motion Picture Patents Co. v. Universal Film Mfg. Co., 243 U.S. 502 (1917). See text at note 35 infra.

2. Report of the Attorney General's National Committee to Study the AntTTRUST Laws 145 (1955) (hereinafter cited as ATT'Y GEN. REP.).

3. Ibid.

4. A similar distinction can be made in the field of price discrimination. Thus price discrimination may be used to increase revenue or to drive out competitors. The RobinsonPatman Act, for example, embodies the assumption that cutting the price of a product in a discriminatory manner is a means of driving out competitors and creating monopoly, whereas the economic analysis stresses its usefulness in maximizing monopoly revenue. 
involved and the buyers of the first product have a second product forced upon them. But if the tying sale is only a means of utilizing effectively a power already possessed, different conclusions may well be reached about the propriety of the practice than if the tie-in created a second monopoly beyond the scope of the first. The term "Ieverage," in this article, specifically describes the establishment of a new or second monopoly. The existence of such leverage depends upon the effect of the tying arrangement on the output of the tied product. If the tying seller is maximizing his return on the tying product and the same output of the tied product can still be produced under circumstances consistent with competitive production of the tied product, no additional or new monopoly effect should be assumed. ${ }^{5}$ Conversely, if the amount of production of the tied product is less than any output which could exist when the return on the first product can be maximized, a monopoly in the tied product has been created. The description of this effect as leverage derives from the economic concept of monopoly as the equivalent of control over supply. A finding that supply is not restricted is a finding that no monopoly has been created.

Analysis of the situations in which sellers find tie-ins useful casts doubt upon the validity of the statement that the only purpose of tie-ins is monopolistic exploitation. Present legal methods of treating tying contracts are based upon a false notion of leverage. When the suggested definition of leverage is employed, analysis reveals the need for critical revaluation of the law in this area.

\section{An Analysis of Tying: Five Examples}

\section{The Tie-in, a Monopoly Problem}

To sell or lease one commodity, the tying product, advantageously on condition that it be used with another commodity, the tied product, requires the existence of monopoly power - in economic theory, the ability to control supply. A competitive supplier, selling at the prevailing price and attempting to impose a tie-in upon a buyer, would merely be displaced by a seller who did not." "It is plain," Professor Watkins has pointed out, "that the sale or lease of one article upon condition that a stipulated quantity or number of another article or articles be bought or leased from the same concern imposes a handicap, other things being equal, upon the distribution of the first article. ... Under freely competitive conditions, therefore, the adoption of the policy of the tying contract would tend to hinder distribution of one product as much as it fostered

The usefulness of discrimination as a monopoly-creating device is dubious. See McGee, Price Discrimination and Competitive Effects: The Standard Oil of Indiana Case, $23 \mathrm{U}$. Cнr. L. Rev. 398, 399 n.3 (1956).

5. Monopoly is commonly described as the power to set a price. Where the sale of only one product is involved, the definition is satisfactory because price and output are inversely related. To change the price is to change the output. With a tie-in, however, under certain circumstances a supplier may raise the price of the tied product and lower the price of the tying product without affecting the output of the former. Consequently supply restriction on the tied product must be emphasized here.

6. If the tying seller gave a compensating advantage to the buyer, he might not be displaced. But in that event the tie-in would no longer be useful. 
distribution of the other or 'tied' product. There could be no advantage in the employment of such a policy ....."7

The idea of a compensating disadvantage advanced by Professor Watkins is not unique to free competition. It might equally well be applied to a monopoly situation. A monopolist cannot necessarily improve his position-increase his monopoly revenue-by imposing restrictions on his customers. A monopolist who is charging a price which maximizes his return under given demand and cost conditions is still confronted by the problem of imposing an additional restriction on his customers-the equivalent of a higher price-without giving up as much as he gains. To put the problem in this form is to emphasize the central prerequisite for a successful tie-in: what is sacrificed in the way of return from the sale or lease of the tying product must be more than compensated by increased return from the tied product. ${ }^{8}$ Four different situations may be suggested in which tying might give rise to an increased return. These include evasion of price regulation; single product discrimination, a counting device; product complementarity in a variable proportion context; and technological interdependence, a questionable case. A fifth example is also discussed, which appears to involve a tie-in but is to be explained by economies of joint production or sale.

\section{Evasion of Price Regulation}

Whenever two products are used together in fixed proportions, such as one bolt and one nut, a cup and a saucer, or a left shoe and a right shoe, from the buyer's point of view the two together might as well be a single product. The price of the combination is the only matter of interest. Certainly the buyer of a fifteen dollar pair of shoes does not care when he is told that the left shoe costs ten dollars and the right one only five. Furthermore, a monopolist who sold one part of such a combination while the other part was sold competitively could exact as much monopoly revenue from the sale of one part as from the sale of both. Here is a monopoly case-more precisely a nondiscriminating monopoly case-comparable to that described by Professor Watkins in the area of free competition-an illustration of compensating disadvantage. For example, if the price of bolts were set by a monopolist and the price of nuts were set by competition, tying the sale of nuts to the sale of bolts would not increase the monopoly profit. Every increase in the price of nuts, even if the monopolist could produce them as cheaply as competitors, would require reduction in the price of bolts by a compensating amount. If the monopolist acted otherwise, he would be creating a situation which reduced his total monopoly return. ${ }^{0}$

7. Watkins, Public Regulation of Conpetitive Practices in Business EnterPRISE 220-21 (3d ed. 1940).

8. The right to buy a product from whom one chooses and the availability of alternative sources of supply is a consideration in the purchase when no tie-in is present. Therefore the demand for the tying product at any price will be less than the demand before the imposition of the tie-in. The effect of the tie-in must more than compensate this loss.

9. This conclusion follows when one and only one price for the combination of one boit 
If the assumption that the bolt monopolist is free to set the bolt price at the level maximizing his return is abandoned-if, for example, the government were to place a ceiling on the price of bolts and leave the price of nuts uncontrolled - a tying arrangement would become beneficial. By this means, the seller could increase the nut price to maintain the profit-maximizing price for the boltnut combination. Only when freedom to set the price of the monopolized product is denied can a tie-in of two products used in fixed proportions become useful. ${ }^{10}$ This principle, however, does not limit the evasionary use of a tie-in to the fixed proportion case alone. Wartime whiskey purchasers, for example,

and one nut can be set. Then setting the price of one component will maximize monopoly profit. Thus, if cost of producing a bolt or a nut is one cent-two cents for both-and the demand for the combination is as shown in the following table's, the maximizing price for the nut-bolt combination can be demonstrated.

If a monopoly in both products is assumed:

\begin{tabular}{cccrr}
\hline \hline $\begin{array}{c}\text { Price of one mut } \\
\text { and one bolt }\end{array}$ & $\begin{array}{c}\text { Demand for one } \\
\text { mut and one bolt }\end{array}$ & Revemue & Cost & $\begin{array}{r}\text { Total } \\
\text { profit }\end{array}$ \\
\hline$\$ .06$ & 1000 & $\$ 60.00$ & $\$ 20.00$ & $\$ 40.00$ \\
.05 & 2000 & 100.00 & 40.00 & 60.00 \\
.04 & 3000 & 120.00 & 60.00 & 60.00 \\
.03 & 4000 & 120.00 & 80.00 & 40.00 \\
.02 & 5000 & 100.00 & 100.00 & 0 \\
\hline
\end{tabular}

The following table shows that equally large profit can be made merely by fixing the bolt price if nuts are competitively sold:

\begin{tabular}{ccccc}
\hline \hline $\begin{array}{c}\text { Bolt price when } \\
\text { muts sell for } \\
1 \text { cent }\end{array}$ & $\begin{array}{c}\text { Bolt demand } \\
\text { (nnts 1 cent) }\end{array}$ & $\begin{array}{c}\text { Bolt } \\
\text { revente }\end{array}$ & $\begin{array}{l}\text { Bolt } \\
\text { cost }\end{array}$ & $\begin{array}{l}\text { Bolt } \\
\text { profit }\end{array}$ \\
\hline$\$ .05$ & 1000 & $\$ 50.00$ & $\$ 10.00$ & $\$ 40.00$ \\
.04 & 2000 & 80.00 & 20.00 & 60.00 \\
.03 & 3000 & 90.00 & 30.00 & 60.00 \\
.02 & 4000 & 80.00 & 40.00 & 40.00 \\
.01 & 5000 & 50.00 & 50.00 & 0 \\
\hline
\end{tabular}

Thus in this fixed proportion situation, a monopoly of bolts if nuts are competitive is as good as a monopoly of nuts and bolts. If nuts are not competitive, the bolt monopolist has an interest in making them so, but no tie-in is required to achieve a lower price for nuts.

10. An example may be found in the facts of FTC v. Gratz, 253 U.S. 421 (1920). See Stevens, Tying Arrangements, in Conference on the Anttruust Laws and the AtTorNEY GENERAL's COMNITTEE REPORT 145-47 (1955). In Stevens' summary: "[T] he respondent was a jobber who sold most of the steel ties used for wrapping cotton bales (six ties were required for each six yards of bagging), and also jute bagging used in connection with the ties. These ties (for a limited period) were sold by the respondent only on condition that the jute bagging for the cotton bales would also be purchased from it." Gratz, selling to customers requiring cotton ties and bagging in fixed proportion, apparently found the Carnegie Steel policy of low steel prices in wartime could be circumvented by charging for bagging, through a tie-in, what could have been exacted from steel ties had he been free to raise that price. Stevens indicates that it was the "shortage" of steel which enabled the respondents "to make hay with the jute bagging." But the shortage was not the factor which made this tie-in useful. Inability to raise the price of the steel ties caused the seller to search for another method of maximizing return. 
bought unregulated rum and wine in order to secure price-controlled whiskey. The sellers were thus able to employ tie-ins advantageously even though whiskey and rum need not be used in fixed proportions.

Where fixed proportions are involved, no revenue can be derived from setting a higher price for the tied product which could not have been made by setting the optimum price for the tying product. The imposition of a tie-in under these circumstances determines the identity of the seller, but the amount of the tied product actually sold will not differ at all from that which could be sold if the optimum price for the tying product were set. ${ }^{11}$ Another monopoly is not created. The seller has only established a new method of exercising his already existing monopoly in the regulated product. Leverage, therefore, does not exist when the proportions of the two products are fixed.

\section{Single Product Discrimination-A Counting Device}

A similar conclusion follows when different buyers use different quantities of the second commodity with one unit of the first. If the first commodity is worth more to the intensive users than to the less intensive users-in economic terms, if the formers' demand is less elastic-tying the second commodity to the first can in effect achieve the goal of discriminatory pricing for the first. ${ }^{12}$ In this situation, the tied product serves as a counting device to measure how intensively the first product is being used. ${ }^{13}$

An illustration may perhaps be drawn from an early tying case. ${ }^{14} \mathrm{~A}$ machine was invented for stapling buttons to high-button shoes, an operation formerly done by hand at higher cost. The patentee had a number of prospective customers for his machine, some of whom made a great many shoes, others only a few. The invention saved each user a fixed amount on each button attached. Thus the machine was worth more to the more intensive users. If the patentee attempted to sell it at different prices to the different users, however, he would have encountered two problems. To determine in advance how intensively each buyer would use the machine would have been difficult; to prevent those who paid a low price from reselling to those who paid a high price might have proved impossible. A tie-in would resolve these difficulties. The machine might be sold at cost, on condition that the unpatented staples used in the machine be bought from the patentee. Through staple sales, the patentee could obtain

11. Critics of the Robinson-Patman Act make the same point when they suggest that harm to competitors, caused by discrimination, is not to be confused with harm to competition.

12. This effect is recognized by most texts on monopoly pricing. See, e.g., STIGLER, The TheORY of PrICE 214-18 (rev. ed. 1952). Stigler lists three essential conditions for discrimination: first, the markets must be separable; second, since discrimination is pointless when elasticities of demand are the same or nearly the same, demands in the separable markets must be considerably different; and third, the cost of separating, or keeping the markets separate, must not be too large. Id. at 215 .

13. See Director \& Levi, Law and the Futnure; Trade Regulation, 51 Nw. U.L. REv. 281, 291-92 (1.956).

14. Heaton-Peninsular Button-Fastener Co. v. Eureka Specialty Co., 65 Fed. 619 (C.C.W.D. Mich. 1895). 
a device for measuring the intensity with which his customers used the machines. Hence by charging a higher than competitive price for the staples, the patentee could receive the equivalent of a royalty from his patented machines. ${ }^{15}$

Although a tying sale may thus be used as a "counting device" for setting discriminatory prices on the tying product, the patentee creates no new and additional monopoly over the tied product. He could have achieved exactly the same return by attaching a meter to the button-stapling machine to measure the intensity of use, leasing the machine and charging a meter rate. ${ }^{16} \mathrm{As}$ in the first example, tying is used simply as a means of insuring the full monopoly return on the tying product, where a monopoly already existed. No leverage can be found because the output of tied product, staples, is exactly the same when machine payment is charged directly and staples are sold competitively as when the staples are tied to the machine. The two outputs under the two equivalent methods of discrimination are identical.

Although the use of a tie-in sale as a counting device is consistent with the facts of a large number of tying cases-for example, the tying of ink to mimeographs, punch cards to computors or rivets to riveting guns-it does not provide the only rational explanation of tying practice when variable proportions are involved. The example suggests a means by which a monopolist can separate markets to achieve the maximum return from each of the various markets in which the single product can be sold. In this instance, the higher price charged for the tied product is in lieu of the proper pricing of the tying product without the tie-ins. But the fact that profit maximization on only a single product is involved must be emphasized. The example takes no account of the possible effect that the price or the quantity sold of the tying product may have on the sales of the tied product, or of the effect that the price or the quantity sold of the tied product may have on the sales of the tying product when the demands for the two are related. ${ }^{17}$

15. The same "discrimination" result could conceivably have been achieved by giving the machine away and charging a still higher price for staples, except for the fact that the machine might be provided to infrequent users. Under these circumstances the patentee might not even secure a return which would cover the cost of supplying the machine. See text at note 59 infra.

16. Although each user of a patented button-fastening machine pays the same rate per pair of shoes manufactured, use of the tying device or of a meter has the effect of a different sales price for the machine according to intensity of use. This is discrimination, since the large user pays the higher price. When the desired result is to charge the less intensive user the higher price, the tie-in is ineffective. Whether or not the machine manufacturer's royalty comes from the sale or lease of the machine or from the sale of the staples or the buttons, the maximum that can be charged is fixed by the amount the machine saves the machine users. If the users to whom the machine is "worth" more can be charged more for the machine, either in the form of a machine charge or indirectly by compulsory purchase of a tied product, the patentee is being rewarded for his machine patent. Interestingly enough, Mr. Justice Lurton used almost precisely this reasoning in deciding both Heaton-Peninsular Button-Fastener Co. v. Eureka Specialty Co., 77 Fed. 288 (6th Cir. 1896), and Henry v. A. B. Dick Co., 224 U.S. 1 (1912).

17. Maximization of profit for one product when demands are related requires an assumption about the price or output of the other, and the joint maximization from the 


\section{Product Complementarity in a Variable Proportion Context}

If two products complement each other, so that an increase in the price of one will not only result in fewer sales of that product but also in fewer sales of the other, the price which maximizes return from the sale of one will depend upon the price at which the other sells. If product $A$, for which no close substitutes exist, is sold by only one seller, and product $B$, its complement, is offered by many competing sellers, the maximum monopoly profit from the sale of $A$, arising from the "best" price of $A$ when $B$ is competitively priced, may possibly be increased by tying the sale of $B$ to the sale of $A$. Increase of the total profit will depend upon the existence of a situation-unlike the first example-in which the profit lost on sales of product $A$ by imposition of the tie-in is more than compensated by the profit obtained from the higher price charged for product $B$. This condition alone is the generalization which explains the rational use of any tie-in. When cross-elasticity of demand is involved, a price increase in one product affects the demand for the other. Thus in the first example, the price of left shoes will influence the demand for right shoes and the price of right shoes will affect the demand for left shoes in the same manner. On the other hand, when two complements are used in variable proportions, even after the market has been separated into segments in which different prices can be charged-the counting device-the cross-elasticity of the complements creates the condition calling for two distinct prices in order to maximize profit, just as if a single firm had the monopoly of each product. When product complementarity is involved, the higher price charged for product $B$ is not a substituted means of charging for product $A$. On the contrary, output of product $B$ for use with product $A$ is less than any output of product $B$ for such use which would exist by manipulation of the price or output of product $A$ when product $B$ is competitive. In other words, the result of the tie-in is to create the equivalent of another monopoly, a monopoly over product $B$ for use with product $A$. The tie-in thus yields the equivalent of monopoly by a single seller over both $A$ and $B .{ }^{18}$ Leverage is present; and the tie-in provides the

sale of both calls for setting the price of each. The geometric solution of such a twomonopoly case is set forth in detail, although not related to the tie-in problem, in Bailey, Price and Output Determination by a Firm Selling Related Products, 44 Axr. Econ. Rev. 82 (1954). See also Alien, Mathematical Analysis for Economists 350 (1949).

18. The distinction between this example and the foregoing "counting" example resolves itself into this question: does a monopoly over the tied product, or part of it, add any profit over what could be achieved by manipulating the price of the tying product, in absence of control over the tied product. If two products have interrelated demandseither substitutes or complements-a seller can realize more aggregate profit from setting. the two prices together than by setting the two prices independently. Having both monopolies under one management can be better than having the monopoly of $A$ when $B$ is competitive. See Bailey, supra note 17 . When the demand interrelationship between two products is complementary and the proportions of use between the products are inseparable for purposes of discrimination, a tie-in allows the monopolist of the tying product to become a monopolist of the tied product for all its uses which require the tying product. In contrast, the counting case maximizes, when prices are set and complementarity exists, only by transforming a variable proportion market into a number of separable fixed pro- 
leverage, since the price and output of one product will necessarily affect the price and output of the other. ${ }^{19}$ Of the three examples given, only under these

portion markets. If, with the product complementarity, the tied product has no use except with a patented tying product, then the tie-in can achieve a result which is indistinguishable from that which would exist had the patentee been granted a patent on both the tying and the tied.

The following example has been constructed to illustrate the use of a tie-in to create a second monopoly (leverage) :

Suppose that patented product $A$ is a new product which is useful only with a second unipatentable product which in turn is useful only with the first. Suppose further that either product $A$, the patented product, or $B$, the unpatented product, costs $\$ 2.00$ to produce no matter how many are made. Now assume that product $B$ will sell competitively at $\$ 2.00$. The following table gives demand conditions calling for a $\$ 4.00$ price for $A$ :

\begin{tabular}{lcccc}
\hline \hline $\begin{array}{l}\text { Price of } \\
A\end{array}$ & $\begin{array}{c}\text { Demand for } A \\
\text { when price of } \\
B \text { is } \$ 2.00\end{array}$ & $\begin{array}{c}\text { Total } \\
\text { revente }\end{array}$ & $\begin{array}{c}\text { Total } \\
\text { cost }\end{array}$ & Profit \\
\hline$\$ 5.50$ & 500 & $\$ 2750$ & $\$ 1000$ & $\$ 1750$ \\
5.00 & 1000 & 5000 & 2000 & 3000 \\
4.50 & 1500 & 6750 & 3000 & 3750 \\
4.00 & 2000 & 8000 & 4000 & 4000 (maximum) \\
3.50 & 2500 & $\$ 750$ & 5000 & 3750 \\
3.00 & 3000 & 9000 & 6000 & 3000 \\
2.50 & 3500 & 8750 & 7000 & 1750 \\
\hline
\end{tabular}

If the complementary relationship between $A$ and $B$ is such that every $\$ 0.50$ increase in the price of $B$ decreases by 100 the amount of $A$ that may be sold, and that every $\$ 0.50$ increase in the price of $A$ decreases by 200 the amount of $B$ that can be sold, then the two discrete monopoly prices which maximize returns for both products (assuming only one nondiscriminatory price for each can be set) can be calculated once the demand for $B$ at a particular $A$ iprice is given. Assume, therefore, that when $A$ is priced at $\$ 4.00 B$ demand will be as follows:

\begin{tabular}{cc}
\hline Price of $B$ & Demand for $B$ when the price of $A$ is $\$ 4.00$ \\
$\$ 5.50$ & 200 \\
5.00 & 700 \\
4.50 & 1200 \\
4.00 & 1700 \\
3.50 & 2200 \\
3.00 & 2700 \\
2.50 & 3200 \\
2.00 & 3700
\end{tabular}

At the competitive price of $\$ 2.00,3700$ of $B$ product can be sold when product $A$ is priced at $\$ 4.00$. Now the holder of the patent on product $A$, by insisting that none of his $A$ product will be sold except on the condition that all $B$ product used with $A$ will be purchased from him, and by lowering the price of $A$ to $\$ 3.50$ and raising the price of $B$ to $\$ 3.50$, can substantially increase his monopoly profit. Monopoly profit prior to the tie-in was $\$ 4000.00$, as indicated by the first table. Tying the sale of product $B$ to product $A$ and selling each for $\$ 3.50$ makes possible the sale of 2200 of $A$ netting $\$ 3300.00$ and 2400 of $B$ netting $\$ 3600.00$ for a total profit of $\$ 6900.00$ on both.

19. The tie-in here is only useful to the seller if the maximizing price of the tied product is above its competitive price. If the "best" price for the tied product were lower 
circumstances does a tying sale create leverage. ${ }^{20}$ Thus, as the term is used in this article, leverage did not exist in the counting case because the same result could have been obtained by metering the first product with no control over the second. In the complementarity case, however, control over the second product, product $B$, is required even though latent power over product $B$ may be said to reside in product $A$ for those uses of $B$ with $A$. Here, in the complementarity case, control over $B$ is essential to securing revenue which could not be realized from $A$ alone; and the tie-in creates the equivalent of a new monopoly of $B$ in addition to the monopoly of the complementary product $A$.

Even though product complementarity exists, a tie-in may not be feasible despite the possibility of increased profits. A pen seller, for example, would have difficulty conceiving of an arrangement assuring that only ink cartridges of his own make were being used with his pen. After a pen sale, the cost of policing the tie-in would be prohibitive. And leasing a ballpoint pen is hardly to be recommended in the name of sound merchandising. But if, rather than pens and cartridges, an example of two complementary machines is assumed, and if for two maximizing sale prices equivalent lease rental charges are substituted, a tying arrangement will result in increased profits. ${ }^{21}$ The United Shoe Machinery Company, for example, made extensive use of the practice of leasing a monopolized or patented machine only on the condition that another machine-either unpatented, unmonopolized or precariously monopolizedwould also be rented. ${ }^{22}$

\section{Technological Interdependence}

The usefulness of a particular product or device may depend not only upon its own adaptability but equally upon the adaptability of some essential comple-

no tie-in would be needed. Consumers, presumably, would not have to be forced to pay less than the going market price.

20. The tie-in as a counting device can be viewed as a means of stopping leakages between markets. Single product discrimination requires that the markets be separated. See note 12 supra. In contrast, the solution in this example arises irrespective of leakage. Even if perfect price discrimination on the tying product could be achieved without the use of a tie-in, the tying mechanism could still be utilized to maximize return on the tied product as well. This follows from indifference analysis concerning individual consumer behavior in the presence of complementary goods. Thus, if the market for bacon and eggs consisted of only one customer, his indifference or preference for various combinations of these two products may be such that, given a bacon and egg budget, he would derive more satisfaction from an expenditure in which bacon was sixty cents a pound and eggs thirty cents a dozen then if each sold for forty-five cents. See Hicks, Value and Capital $42-45$ (1948) ; Hayek, The Geonetrical Representation of Complementarity, 10 REv. of EcoN. STudies 122 (194243).

21. A machine and a product would provide an equally good example. The buttonfastening machine and the staples, used as an illustration of a counting device, might conceivably involve interrelated demands as well. The two discrete prices could add some monopoly in addition to the advantage achieved by counting.

22. See United States v. United Shoe Mach. Co., 247 U.S. 32 (1918). 
ment. If the essential complement did not conform to exact specifications, it might impair the operation or usefulness of the principal product. For example, if a very slight imperfection in an unpatented card were to make a patented tabulating machine operate inefficiently, or in a more extreme case actually cause costly damage, a patentee lessor or seller of such a machine would have an understandable interest in protecting the good will which arises from satisfactory performance. When the exact source of poor performance is difficult to trace, the supplier will be especially concerned that no foreign elements are being used with his machines. This defense for tying clauses has often been raised in the litigated cases. Thus in Henry $v$. A. B. Dick Co., defendant claimed that ink supplied by others would or might impair the proper functioning of a mimeograph machine which he manufactured. ${ }^{23}$ Nor is the example of cards and tabulators fanciful; such a defense was invoked in a tying case by I.B.M. ${ }^{2 *}$ Again, in the early shoe machinery cases, the United Company stressed the very close technological interdependence of a wide variety of machines each of which, although doing a separate task, was only efficient if properly co-ordinated with the others.25

In many cases involving technological interdependence, a careful description of the specifications necessary for successful performance might overcome the objections of the manufacturer. However, in one respect interdependence differs from the other examples described: the interests of the prospective "tyer" and the "tyee" are not in conflict. Each has a rational interest in technological efficiency. One would rarely expect objections from a buyer or lessee that a complementary product is being forced upon him, if the technological reasons advanced by the seller are valid. ${ }^{26}$ In the Pick case, General Motors insisted that its dealers sell and install only those parts authorized by the company. ${ }^{27}$ The substance of the court's holding was that substandard parts installed in a General Motors car by a General Motors dealer would have a deleterious effect on the company's good will because users would not ordinarily associate the improper functioning of their automobiles with the use of non-General Motors parts. Why the dealers' interest in this problem should not parallel that of General Motors was not discussed in the case. An absence of conflict of interest at least would support a strong presumption that the difficulties arising from problems of technological interdependence between products can be resolved by means other than tying contracts.

23. 224 U.S. 1 (1912).

24. International Business Machines Corp. v. United States, 298 U.S. 131 (1936).

25. United States v. United Shoe Mach. Co., 247 U.S. 32 (1918).

26. When the supplier of a patented item is a strong, responsible and financially stable company and the competitive suppliers of the complementary item have opposite characteristics, the user of the complements is likely to express dissatisfaction with the results of the combination to the stronger patentee. In this situation, withdrawal of a guarantee by the patentee, unless acceptable complements are used, would seem to involve no more than fair business practice, even though in effect the buyer becomes tied.

27. Pick Mfg. Co. v. General Motors Corp., S0 F.2d 641 (7th Cir. 1935). 


\section{Economies of Joint Production or Sale}

Occasionally tie-ins are alleged to exist under circumstances in which no tying is intended and in fact no tie-in, in any economic meaning of the word, can be found. Probably no one has bought shoes without buying shoelaces at the same time, and the sale of that combination of mechanical parts generally called an automobile is not usually thought of as a tie-in. Of course, shoelaces may be purchased separately, as may automobile parts, but this condition does not preclude the possibility that a tie-in is involved. Still, when the cost of producing and selling the combination is less than the cost of producing and selling the parts separately, no tie-in can be said to exist. Cost justification excludes the rational use of a tie-in. No coercion is required when a cost advantage exists, for these lower costs will be reflected in lower prices.

That the separate offering of a complementary product does not preclude the existence of a tie-in is apparent from an extreme example in which the condition imposed on a buyer for not taking both products from the same seller requires the alternative of paying a higher price for one product than for both. In contrast is another extreme example. Suppose the publisher of both a morning and an evening newspaper found that the cost of running a want ad in both papers was no higher than running it in one paper only. For this reason, the publisher quoted the same price for running the ad in both papers as for running it in one, to the disadvantage of a competitor, the publisher of an afternoon newspaper alone. The cost justification assumed in this example should preclude a finding that a tie-in exists. ${ }^{28}$ The larger publisher's finding that resetting the want ads in type for the afternoon paper was more expensive than merely reprinting the morning's ads seems a reasonable basis for his course of action-a case of economy of scale. If such an arrangement were to be struck down, efficient operations would have to be sacrificed.

Use of tying sales is not necessarily conclusive proof that the seller is wielding leverage. The analysis of the motives and purposes which may underlie utilization of the tying device suggests that the legal conclusion of automatic illegality is too facile. The device may be employed to achieve a number of goals, some of which are clearly legitimate. Of the five examples discussed, only one, that of product complementarity in the variable proportion context described, involves leverage.

\section{LEVERAGE AND THE LAW}

The Clayton Act, passed in 1914, contains the only specific statutory language forbidding tie-ins. ${ }^{29}$ In section three of this act, prohibition of tie-ins ex-

28. No necessary relationship to the facts of Times-Picayune Publishing Co. v. United States, 345 U.S. 594 (1953), should be assumed. If a cost justification had been present in that case, defendants would almost certainly have brought it to the Court's attention.

29. 38 Stat. 731 (1914), 15 U.S.C. $\$ 14$ (1952). Section 3 of the act forbids any person "to lease or make a sale or contract for sale of goods, wares, merchandise, machinery, supplies or other commodities, whether patented or unpatented ... or fix a price 
tends to both patented and unpatented products, covers both selling and leasing, but is limited to commodities. The tie-in, to be found illegal, must be likely "to substantially lessen competition or tend to create a monopoly." 30 The section contains no direct reference to leverage, but in a very real sense the conception of the whole Clayton Act depends upon the leverage notion. ${ }^{31}$ The declared purpose of the sponsors of this legislation was to strengthen the antitrust laws by outlawing particular practices. These practices, beyond the reach of the Sherman Act, were believed to lead to or "ripen into" monopoly. Among such practices, tying arrangements were emphasized. The very language "substantially lessen competition or tend to create a monopoly" reflects the leverage presumption.

The relationship of tying to the creation of monopoly-the leverage problem -had been faced by courts in the area of patent law before the passage of the Clayton Act. In the Button-Fastener case, the Court of Appeals for the Sixth Circuit considered a patentee's right to sell a patented machine for stapling buttons to shoes with the attached condition that staples be purchased from the patentee. $^{32}$ The court decided the issue in favor of the patentee. However the tie-in question was not presented to the Supreme Court until 1912, sixteen years later. In a four to three decision Mr. Justice Lurton, who had decided the earlier Button-Fastener case, came to the same result when considering the tying sales of a mimeograph machine on condition that ink, stencils, paper and other supplies be bought from the patentee. ${ }^{33}$ A vigorous dissent was entered by Mr. Justice White. Stripped to its essential logic, the dissent advanced the proposition that a tie-in to a patented commodity was the equivalent of allowing a monopoly over the tied product. ${ }^{34}$ This additional monopoly, White reasoned, went beyond that granted to the patentee and should not be protected by the patent law.

This "patent extension" argument of the minority became the majority opinion five years later in the Motion Picture Patents case. ${ }^{35} \mathrm{Mr}$. Justice Clarke's opinion makes an unmistakable reference to leverage:

charged therefor, or discount from, or rebate upon, such price, on condition, agreement or understanding that the lessee or purchaser thereof shall not use or deal in the goods, wares, merchandise, machinery, supplies or other commodities of a competitor or competitors of the lessor or seller, where the effect of such lease, sale, or contract for sale or such condition, agreement or understanding may be to substantially lessen competition or tend to create a monopoly in any line of commerce."

30. Ibid.

31. 'See Atr'y Gen. Rep. 129.

32. Heaton-Peninsular Button-Fastener Co. v. Eureka Specialty Co., 77 Fed. 288 (6th Cir. 1896).

33. Henry v. A. B. Dick Co., 224 U.S. 1 (1912).

34. "[T] hat which was not embraced by the patent, which could not have been embraced therein and which if mistakenly allowed and included in an express claim would have been inefficacious, is now by the effect of a contract held to be embraced by the patent and covered by the patent law." Id. at 51 .

35. Motion Picture Patents Co. v. Universal Film Mfg. Co., 243 U.S. 502 (1917). 
"Such a restriction is invalid because such a film is obviously not any part of the invention of the patent in suit; because it is an attempt, without statutory warrant, to continue the patent monopoly in this particular character of film after it has expired, and because to enforce it would be to create a monopoly in the manufacture and use of moving picture films, wholly outside of the patent in suit and of the patent law as we have interpreted it."36

This legal conclusion relating to patent tie-ins has remained substantially unchanged for forty years. When the sale or lease of a commodity is tied to a patented product, the tie-in is considered per se illegal. ${ }^{37}$ No exceptions to the rule have emerged since its establishment; and indeed its acceptance may be gauged by the fact that no defendant has even questioned the doctrine in recent years. ${ }^{38}$

The attitude of the law toward tying to unpatented products, covered by section three of the Clayton Act, is not so clear. Although the per se rule has no application here, a recent summary of the law by the Supreme Court in the Times-Picaynme case does profess to narrow the area for relevant inquiry. ${ }^{39}$ According to this opinion, a court may find illegal activity, in the absence of a patent on the tying product, whenever the supplier enjoys a monopolistic position in the tying product or if a substantial volume of commerce in the tied product is restrained." For purposes of economic analysis this "clarification" is not helpful. A tie-in is a useless device unless the supplier possesses subtantial monopoly over the tying product. How much economic monopoly must exist before the law's monopoly, which will result in illegality, may be found? In determining whether a substantial volume of the tied product is restrained, should a lower court emphasize "substantial" or "restrained"? If the former, the equivalent of the "quantitative substantiality test" of the Standard Oil Company case suggests itself. ${ }^{41}$ If the latter, application of the kind of criteria embodied in an economic description of leverage seems proper. These questions must be answered if the advice about tie-in law in the absence of patents given in Times-Picayune is to be of use. To attempt to provide answers to these broader problems, however, is beyond the scope of an article concerned with leverage.

36. Id. at 518 .

37. The rule of per se illegality operates only if the volume of the tied supplies is "significant." See International Salt Co. v. United States, 332 U.S. 392, 396 (1947). Sale of the patented machine was involved in Motion Picture Patents Co. v. Universal Film Mff. Co., 243 U.S. 502 (1917). Subsequently, in United States v. United Shoe Mach. Co., 247 U.S. 32 (1918), a machine lease was distinguished and the tie-in allowed under patent law. In a later case brought under $\S 3$ of the Clayton Act and involving the same facts, the result was reversed. See United Shoe Mach. Corp. v. United States, 258 U.S. 451 (1922).

The term "patented product" includes a machine, a process or a combination as well as a commodity.

38. As a measure of the doctrine's present accepted status, see ATT'y GEN. REP. 145.

39. Times-Picayune Publishing Co. v. United States, 345 U.S. 594 (1953).

40. Id. at 608 .

41. Standard Oil Co. v. United States, 337 U.S. 293 (1949). See ATT'Y Gen. REp. 141. 
Leverage necessarily involves the creation of new monopoly. Only when the original monopoly can be assumed to serve some useful public purpose, as in a patent situation, need the relevance of the leverage question arise. If the first monopoly is without conceivable justification, the creation of a second is irrelevant to the public interest. Either the justifications for the first monopoly should be attacked directly, or, if the first is an acceptable monopoly, the effect of tying should be scrutinized to determine whether it leads to the establishment of an unacceptable second. The following evaluation is confined to the leverage problem as it relates to an acceptable first monopoly, here exemplified by the existence of the patent.

\section{Evaluation of Patent Tie-in Law in Ternis of Leverage}

Writing a fifth and concluding part of a long article on patent practice and the antitrust laws in 1942, Mr. Giles Rich summarized what a patentee may legitimately do in exercising his right to exclude others from making, vending or using his invention. ${ }^{42}$ The patentee has the right to maximize the monopoly profit from the invention. He can sell or not sell, lease or not lease. He can restrict production or fix the price of his own sales or the sales of his licensees. ${ }^{43}$ What a patentee may do involves "restraining trade and maintaining a monopoly, but permission to do so with respect to inventions is the basis of the patent system. This is the reward offered to induce invention, disclosure and enterprise."44 Mr. Rich then provides several examples of licensing which are clearly permissible because they make possible only a more profitable exploitation of the proper patent monopoly. Examples of permissible practice include the retention or reservation by a patentee of a particular field of use for himself or for others; a reservation of this kind is allowed even though the other fields of use have been licensed to someone else. Such division of fields is permissible because it has not "created a monopoly in anything more than the patented invention." 45 A reservation or a division of geographical areas leads Mr. Rich to exactly the same result. "Nothing has been added to the patent monopoly."46 A similar conclusion is also reached about restrictions upon a licensee's output. "He has not enlarged his monopoly nor has he extended it to anything other than the invention protected by the patent."47 Summarizing his conclusions, Mr. Rich cites with approval the Motion Picture Patents case to the effect that a patentee's monopoly cannot be expanded beyond the boundaries claimed:

"The test is always the same: will the enforcement of the restriction be a mere enforcement of the right to exclude others from making, using, or

42. Rich, The Relation Between Patent Practices and the Anti-Monopoly Laws, 24 J. PAt. OFf. Soc'y 422 (1942).

43. Id. at 424 .

44. Ibid.

45. Id. at 425 .

46. Ibid.

47. Id. at 426. (Emphasis added.) 
selling the patented invention or will it enlarge the rights of the patentee as against the public? If to enforce it gives a partial monopoly in an unpatented commodity, there has been an extension." 48

This test which Mr. Rich applies is the equivalent of the question posed in this Article: is leverage involved? Mr. Rich then goes on to conclude, without proof, that tie-ins inevitably involve monopoly over a second product. One need not disagree with any of Mr. Rich's conclusions to hold the position that if a patent tie-in can be found which does not involve leverage, it cannot be ruled illegal by the logic of the leading cases. The finding that leverage exists has been the central determinant to a reasoned conclusion that patent tie-ins should not be allowed.

Although a rule holding illegal the sale or lease of a patented product or machine to which another product is tied is sometimes supported on the ground that the wisdom of a public policy sponsoring any patent monopoly is doubtful ${ }^{40}$ such an argument is in effect a direct attack upon the first monopoly and seems to be a better subject for separate inquiry. The validity of the original monopoly is not questioned here.

Other arguments may be advanced to support the desirability of a per se rule against patent tie-ins, whether or not leverage is present. One would justifiably assert that non-leverage tie-ins foster either the evasion of price regulation, as in the first example, or price discrimination, as in the second, the counting case. A per se rule to stamp out all evasion of price regulation is unacceptable. Given fixed proportions, tie-ins can be used to evade privately regulated as well as publicly regulated prices. But gray markets may result in better allocation of resources than would exist if the fixed prices were observed, ${ }^{50}$ and, unlike black markets, they are not publicly condemned. Moreover, in the combination patent cases, products in fixed proportions cannot be sold without the use of tie-ins; and the interest so protected seems valid. ${ }^{51}$ To make a tie-in illegal in the price discrimination situation is arbitrary, for it resolves a very complicated problem in a manner totally different from the law directly concerned with price discrimination. If a tie-in is declared automatically illegal because of discrimination, the result is effective elimination of the necessary showing, required even by the Robinson-Patman Act, that "the effect of such discrimination may be substantially to lessen competition or tend to create a monopoly."52 Secondly, the contention that a tie-in prolongs the effective life of a patent rests on a belief that entry will be less prompt after the expiration of a patent, when a tie-in is used, because two entries, one into the field of the tying product and

48. Id. at 427. (Emphasis added.) See Motion Picture Patents Co. v. Universal Film Mfg. Co., 243 U.S. 502, 518 (1917).

49. See Plant, Economic Theory Concerning Patents for Invention, 1 Econosica (n.s.) 30 (1934).

50. See Stigler, The Theory of Price 83-87 (rev. ed. 1952).

51. See text following note 54 infra.

52. 49 Stat. 1526 (1936), 15 U.S.C. $\$ 13$ (a) (1952). See AtT'y GeN. REp. 160-67. 
another into the field of the tied, are then required." The requisite "knowhow" is enlarged, the argument runs, and a longer life for the monopoly is thus created. The argument has no validity when the tied product has other uses than with the tying product, for the essential know-how is already in the market. Moreover, to support the entry argument, the patentee himself must be able to produce everything the market demands. If the patentee buys the tied product from others, using the tie-in to become an exclusive seller of the tied product, the other manufacturers will acquire the know-how. A per se rule takes no account of this common pattern. Finally, know-how concerns the tying product as well as the tied. Once the patent on the tying product has expired, any relevant know-how must also be acquired by new producers of this tying product. The tie-in will only delay entry, therefore, when the time required to obtain tying product know-how is shorter than that for the tied product. Under any other circumstances, no time extension can be attributed to the existence of a tie-in. But if the know-how for manufacture of the tied product is actually longer, no reason may exist for the patentee to establish a tiein in the first place. The relationship of tie-ins to new entry seems far too doubtful to justify per se treatment.

The legal rule which has developed has been based upon an imprecise evaluation of the economic effects of tying practice in extending monopoly. Analytically, the per se rule depends upon a prior finding of leverage. This dependence suggests the relevance of a proposal which would not condemn patent tie-ins when leverage clearly is not involved. No conclusive method can be prescribed which will make possible a neat division of cases into two mutually exclusive categories of "leverage" and "no leverage." A clearer understanding of what is involved in distinguishing the "counting" case and the "complementarity" case might lead to the eventual establishment of a more satisfactory and certainly a more logical legal rule.

Reason neither in law nor economics will justify concern over leverage unless separate prices of both the tying and the tied products are set. Advantageous use of leverage necessarily depends upon effective pricing of the first and the second product. 54 The "one price" cases involving economies of joint production or sale, therefore, might be segregated for exclusion not only from the per se rule, but also from the "illegal" category. Courts now hold illegal certain patent tie-in arrangements in which all the revenue is derived from the sale of a single tied product. Most notable of this category are the familiar combination patent cases, where no part of the combination is patentable and no revenue can be derived without the sale of one of the component products. In the absence of the tie-in, the seller can obtain no royalty from the otherwise perfectly proper licensing of the combination. A number of illustrative cases might be cited, cases in which a tie-in could not have a leverage effect. Among

53. For a fuller discussion of the double entry problem, see Bork, Vertical Integration and the Sherman Act, 22 U. CHI. L. REv. 157, 195 (1954).

54. See note 18 supra and accompanying text. 
them stand such well-known patent tie-in decisions as Carbice, ${ }^{55}$ Mercoid $^{56}$ and $B . B$. Chemical. ${ }^{57}$ These combination patent cases are special examples of the "fixed proportion" type described in the first example. The absence of freedom to set the price of the monopolized product-in these cases, a processmakes this kind of tie-in useful. ${ }^{58} \mathrm{~A}$ patentee of a combination patent cannot enjoin manufacture of the unpatented parts; he lacks any practical means to control their assembly and sale at the retail level; hence, absent tying, he is unable to exercise any freedom in setting the price of that which is monopolized.

A conclusion that leverage cannot exist if only one price is set is not a conclusion that leverage is involved when more than one price is set. Even when a tie-in is used solely as a counting device, and no revenue from an additional monopoly is involved-the second example-the price of the tying as well as the tied product must be so fixed that the equivalent of a minimum charge to protect against nonuse is created. One of the prices serves the sole purpose of eliminating the undesirable customer in the extreme case. ${ }^{59}$ Thus, the existence of a charge for the tying product in addition to the charge for the tied product does not necessarily signal the equivalence of another monopoly. For example, the fact that in both $A . B$. Dick and Button-Fastener ${ }^{60}$ the machines were sold at cost and the staple price and the ink price were raised does not necessarily indicate that two maximizing prices were set, with a resulting creation of leverage.

Factors given no attention in the opinions and illuminated only by ambiguous evidence must be considered before determining whether such cases as ButtonFastener, A. B. Dick, Motion Picture Patents or Shoe Machinery ${ }^{61}$ are "counting" cases or "complementarity" cases. Button-Fastener, for instance, may be viewed more easily than $A$. B. Dick as a "counting" case involving no leverage because only one counter, staples, was involved in the former, while in the latter, the machine was tied to several other products : ink, stencils, paper and other supplies. Any one of them presumably would have provided a perfectly adequate and satisfactory counting device; the counting example cannot explain why all the products are tied. ${ }^{62}$

A counting explanation of the tie-in of films to projectors in the Motion Picture Patents case is even less convincing. Any movie house which is not "dark" is using film, and the amount of film used is an unsatisfactory means of

55. Carbice Corp. v. American Patents Development Corp., 283 U.S. 27 (1931.).

56. Mercoid Corp. v. Mid-Continent Inv. Co., 320 U.S. 661 (1944).

57. B. B. Chemical Co. v. Ellis, 314 U.S. 495 (1942).

58. See text at note 10 supra.

59. This use of the second price has been suggested by Paul MacAvoy, a graduate student in the Economics Department at Yale. His helpfulness in the preparation of this Article deserves general acknowledgment as well.

60. Heaton-Peninsular Button-Fastener Co. v. Eureka Specialty Co., 77 Fed. 288 (6th Cir. 1896).

61. United States v. United Shoe Mach. Co., 247 U.S. 32 (1918).

62. This conclusion would seem to follow unless the multiple tie-in can be assumed to represent the kind of carefulness involved in wearing both belt and suspenders. 
finding the exhibitor who should be paying the highest effective rate for the use of a projection machine. Paid admissions would appear a better measure. Although the record does not show that separate prices were set on the projection machine and the films to produce a return larger than could be received from either, the case is consistent with this rationale, and the alternatives offered are unsatisfactory. Similarly, the complicated Shoe Machinery case, while not susceptible of an easy explanation, in certain aspects fits the analysis of complementarity.

\section{CoNCLUSION}

A finding like that of the complementarity example has not been a legal prerequisite to a conclusion of illegality in tie-in cases. In both Motion Picture Patents and Shoe Machinery, complementarity was not considered. The analysis in this article suggests that the right result may have been reached for the wrong reasons. Doubts must exist about such cases until the relevant information is obtained by something more than pure accident. In the "one price" cases, however, no reasonable basis yet appears for conclusively identifying leverage with tying and automatically declaring tie-ins illegal. At the least, analysis of the patent combination cases suggests their exemption from the per se rule of illegality. More generally, inquiry into the necessary effects of a patentee's adoption of the tying device should be stressed in all patent cases. Outside the patent field, inquiry might be first directed to the monopoly which enables effective use of the tie-in mechanism. Should that monopoly prove consistent with the public interest, examination could then be extended to considerations properly governing patent tie-in cases. 


\section{THE YALE LAW JOURNAL}

ROBERT T. Basseches JEROME H. ReICHMIAN

Comment Editors

ROBERT L. BARD

Thomas D. BARR

William C. Baskin, Jr.

Frederick L. Bernstein

David P. Bicks

Norman A. Bikales

Benjamin W. Boley

Richard A. BRAdy

Newton D. Brenner

David Burres

Peter D. Caldwell

Laura M. Chapanan

Sydney M. Cone, III

Paul H. DeCoster

Robert J. Del Tufo

ROBERT J. ENGELMAN

Mítchel J. Ezer

ARthur Fletscher, JR.
Stephen N. Shulman

Editor-in-Chief

Milton P. DeVAne
Article and Book
Review Editor

Gutdo Calabresi

ALAN J. Hruska

Note Editors

W. L. F. Felstiner

Managing Editor

Seth E. Frank

Thomas N. Fromock

David GoldBerg

Burt W. Griffin

Milton S. GwirtzMan

NEIL S. HECHT

ReUben L. Hedlund

JACOB W. HeLLER

Alan M. HoffMan

JEROLd H. IsRaEI.

STEPHEN J. JELIN

N. Herschet Koblenz

IRVING I. LesNick

MARCIA R. Lockwood

JoHN C. MCGUIRE

FrederICK W. MCNABB, JR.

JoHN K. McNulty

RrCHARd MarLin

Richard M. Meyer

Hugh G. Moulton

Michael J. Nassau

Walter W. Oberreit

Richard W. Pendeton, Jr.

Charles J. Prentiss

Burton RafFex,

Richard Sexton

Dougras O. Smith, $J_{R}$.

LEWIS A. STERN

CoLIN C. TAIT

JOSEPH N. TAUBER

Stanley E. Tobin

JoHN W. VANDoren

Patricia W. Weingerg

T. CECIL Wray, JR.

Alan L. Wurtzel

Marie McMahon

Business Secretary

\section{CONTRIBUTORS TO THIS ISSUE}

Roscoe Pound. University Professor Emeritus, formerly Dean of the Harvard Law School.

Warp S. Bowman, Jr. Associate Professor of Law and Economics, Yale Law School. 